\title{
Development of a direct and specific enzymeimmunoassay for the measurement of oestrone sulfate in bovine milk
}

\author{
G. Hatzidakis, K. Katrakili and E. Krambovitis* \\ Department of Immunology and Diagnostics, Institute of Molecular Biology and Biotechnology, \\ Heraklion, Crete, Greece
}

\begin{abstract}
A 12-step procedure is described for the synthesis of an oestrone-3-sulfate-6-hemisuccinateBSA immunogen with oestradiol as starting material and the production of specific polyclonal antibodies. A competitive inhibition-type enzymeimmunoassay has been developed based on these specific antibodies using 3-hemisuccinate-oestrone-peroxidase as conjugate for direct measurement of the hormone in body fluids. The method has a minimum sensitivity of $0.03 \mathrm{ng} \mathrm{ml}^{-1}$ in bovine milk, and satisfactory specificity, recovery and reproducibility. In a small field trial with a group of 20 pregnant cows that were followed throughout gestation, it was shown that the assay is potentially an accurate pregnancy test for assessing the viability of the fetoplacental unit at approximately 100 days after insemination. The assay is well suited for routine testing, particularly as a confirmatory bovine pregnancy test.
\end{abstract}

\section{Introduction}

Oestrone sulfate is one of the major oestrogens produced by the fetoplacental unit of many animals during pregnancy. The presence of this hormone in the blood and even in the milk of pregnant lactating animals, such as cows, is an accurate indicator of pregnancy with diagnostic applications (Heap and Hamon, 1979; Dhindsa et al., 1981; Saba and Hattersley, 1981; Chaplin and Holdsworth, 1982).

Early methods for measuring oestrone sulfate required hydrolysis and extraction of the hormone to oestrone. The assays used were of the radioimmunoassay-type and measured oestrone or oestradiol (Loriaux et al., 1971; Heap and Hamon, 1979).

Later, antiserum raised against an oestrone-3-glucuronideBSA conjugate allowed direct measurement of oestrone sulfate in samples by radioimmunoassay (Saba and Hattersley, 1981; Holdsworth et al., 1982; Fletcher and Worsford, 1988) and later with an enzymeimmunoassay (Power et al., 1985). Because the sulfate group was replaced in the immunogen by a glucuronide group, the specificity of the antiserum was compromised. The crossreactivity of the resultant antibodies with oestrone was reported to be up to $231 \%$ in relation to oestrone sulfate (Holdsworth et al., 1982).

Nambara et al. (1980) described an approach for the production of a specific antiserum to oestrone sulfate which was used in a direct radioimmunoassay to measure the hormone in human serum and urine (Honjo et al., 1986, 1987). Recognizing the need for a non-isotopic assay that would allow specific and direct measurement of oestrone sulfate, we synthesized a $6 \alpha-$ hemisuccinate-oestrone sulfate derivative which we used to produce specific antibodies to oestrone sulfate and to develop

${ }^{*}$ Correspondence.

Received 20 July 1992. a simple and highly accurate competitive inhibition-type enzymeimmunoassay.

\section{Materials and Methods}

\section{Synthesis of hapten-protein immunogen}

Synthesis of the immunogen involved a total of 12 reactions carried out in four major stages (Fig. 1). All organic solvents and reagents were purchased from Merck (Darmstadt), unless stated otherwise.

Stage (i). Activation of the C-6 position of the starting material, oestradiol (Steraloids, Wilton), was performed as described previously (Longwell and Wintersteiner, 1940). Briefly, oestradiol (I) was acetylated by reflux with acetic anhydride at $140^{\circ} \mathrm{C}$ to give $3,17 \beta$-di-acetyl oestradiol (II), then oxidized with chromium trioxide yielding approximately $10 \%$ 6-keto-oestradiol di-acetate (III) which was de-acetylated with $5 \%$ potassium hydroxide solution in methanol to give 6-keto oestradiol (IV). Thin layer chromatography (TLC) of the product in toluene:ethyl acetate $(5: 1 \mathrm{v} / \mathrm{v})$ gave a single spot. The UV absorbance spectrum gave peaks at 327 and $255 \mathrm{~nm}$ and the melting point was $275^{\circ} \mathrm{C}$. These characteristics agreed closely with the corresponding UV peaks at 326 and $256 \mathrm{~nm}$ and the melting point of $280^{\circ} \mathrm{C}$ which were reported by Longwell and Wintersteiner (1940). The nuclear magnetic resonance (NMR) spectrum confirmed the correctness of the product structure. NMR in $\mathrm{CD}_{3} \mathrm{OD}$ gave the following: $\delta$ p.p.m. $0.7\left(3 \mathrm{H}, \mathrm{S}, 18-\mathrm{CH}_{3}\right), 3.95(1 \mathrm{H}, \mathrm{t} 17 \alpha-\mathrm{H}), 6.85-7.25$ (three aromatic protons q,d,d 2-I-4H).

Stage (ii). A hemisuccinate group was introduced to the activated C-6 position according to Nambara et al. (1974). First, 
(a)

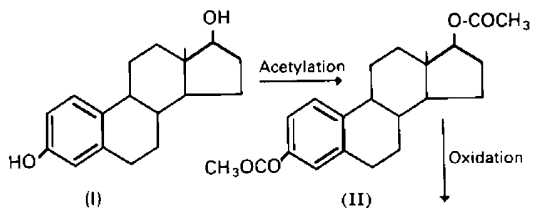

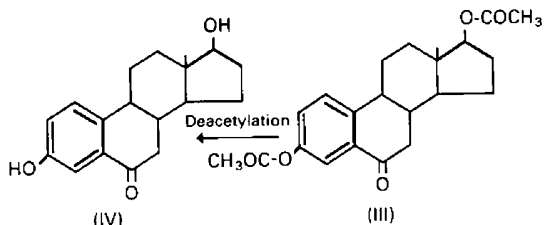

$\downarrow$ Dihydropyran

(b)

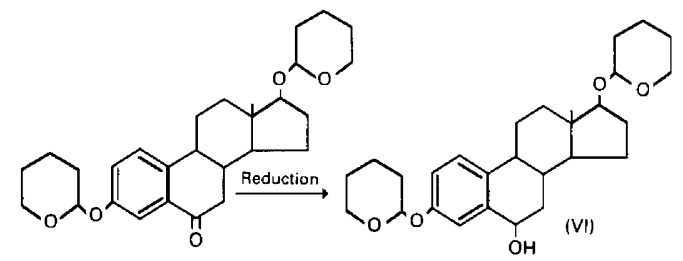

(V)
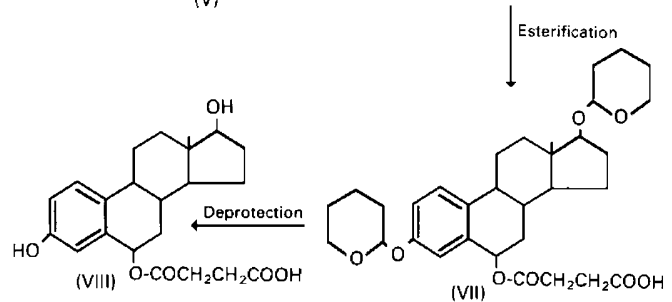

$\downarrow$ Jones reagent

(c)

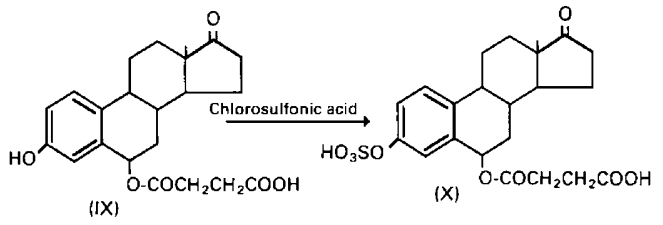

ఏoNitrophenol

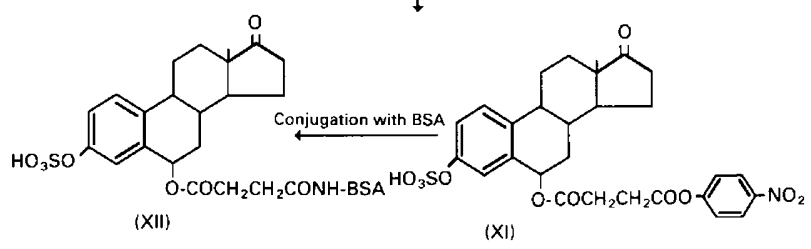

Fig. 1. Synthesis of oestrone sulfate-BSA conjugate used for the production of antibodies.

the hydroxyl groups of the 6-keto oestradiol $(1 \mathrm{~g})$ were protected with $3 \mathrm{ml}$ dihydropyran using a catalytic amount of $p$ toluene sulfonic acid in $16 \mathrm{ml}$ ethyl acetate for $20 \mathrm{~min}$. When a single spot was obtained in TLC (toluene:ethyl acetate, 1:1 v/v) with $R_{\mathrm{F}}$ value of 0.68 , the reaction mixture was diluted with ethyl acetate, washed with $0.5 \mathrm{~mol}$ sodium hydrogen carbonate $\mathrm{l}^{-1}$ and evaporated yielding the diprotected derivative (V). The product was reduced to a 6-hydroxyl derivative (VI) using sodium borohydride. Reaction of the derivative $(1 \mathrm{~g})$ with $1.5 \mathrm{~g}$ succinic anhydride and $2 \mathrm{ml}$ triethylamine in $20 \mathrm{ml}$ dioxane for $20 \mathrm{~min}$ at room temperature gave a 6 -hemisuccinate product (VII). This derivative ( $\mathrm{I} \mathrm{g}$ ) was treated with $50 \mathrm{ml}$ of $0.5 \mathrm{~mol}$ oxalic acid:methanol $l^{-1}(1: 6 \mathrm{v} / \mathrm{v})$ at $70^{\circ} \mathrm{C}$ for $1 \mathrm{~h}$ for cleavage of the dihydropyran ethers. The final product of this stage was $6 \beta$-hemisuccinate oestradiol ( $6 \beta$-hs-oestradiol) (VIII) which was purified after dilution with ethyl acetate and extraction with $0.5 \mathrm{~mol}$ sodium hydrogen carbonate $\mathrm{l}^{-1}$ and acidification of the water-phase with hydrochloric acid to $\mathrm{pH} \mathrm{2.0.} \mathrm{The} \mathrm{product} \mathrm{was}$ filtered and air dried. It was identified as $6 \beta$-hemisuccinate oestradiol with NMR in $\mathrm{CD}_{3} \mathrm{OD}$ : op.p.m. $0.75\left(3 \mathrm{H}, \mathrm{S}, 18-\mathrm{CH}_{3}\right), 2.65$ $\left(4 \mathrm{H}, \mathrm{S}, \mathrm{CO}-\left(\mathrm{CH}_{2}\right)_{2}-\mathrm{CO}\right), 3.65(1 \mathrm{H}, \mathrm{t}, 17 \alpha \mathrm{H}), 5.95\left(1 \mathrm{H}\right.$, broad, $\left.6_{\beta} \mathrm{H}\right)$, 6.6-7.2 (three aromatic protons $\mathrm{q}, \mathrm{d}, \mathrm{d} 2-1-4 \mathrm{H}$ ). The physical properties of the product were: TLC in ethyl acetate: $n$-hexane: ethanol:acetic acid (7.2:1.35:0.45:1.0 v/v) gave an $R_{F}$ value of 0.7 and in chloroform:methanol $(5: 1 \mathrm{v} / \mathrm{v})$ an $R_{F}$ value of 0.5 , whereas the melting point was $165^{\circ} \mathrm{C}$ with a published melting point of $164-166^{\circ} \mathrm{C}$ (Nambara et al., 1980).

Stage (iii). This series of reactions involved the conversion of the oestradiol derivative (VIII) to an oestrone 3-sulfate derivative (Nambara et al., 1980). $500 \mathrm{mg}$ of $6 \beta$-hs-oestradiol was selectively oxidized with $1 \mathrm{ml}$ Jones reagent $(1.5 \mathrm{~mol}$ chromium trioxide $\mathrm{I}^{-1}$ in $2.2 \mathrm{~mol}$ sulfuric acid $\mathrm{l}^{-1}$ ) in $100 \mathrm{ml}$ acetone at $0^{\circ} \mathrm{C}$ for $5 \mathrm{~min}$ to give $6 \beta$-hs-oestrone (IX). After inactivation with methanol and addition of water, the resultant precipitate was filtered and dried. The $\mathrm{NMR}$ in $\mathrm{CD}_{3} \mathrm{OD}$ gave Sp.p.m. 0.9 (3H,S,18- $\left.\mathrm{CH}_{3}\right), 2.65$ (4H,S,-CO- $\left.\left(\mathrm{CH}_{2}\right)_{2}-\mathrm{CO}\right), 6.0$ (1H,broad, $6_{\beta} \mathrm{H}$ ), 6.6-7.2 (three aromatic protons q,d,d 2-1-4H). TLC in ethyl acetate: $n$-hexane:ethanol:acetic acid (7.2:1.35:0.45: $1.0 \mathrm{v} / \mathrm{v}$ ) gave an $R_{F}$ value of 0.73 . The product reacted with chlorosulfonic acid in pyridine to give $6 \beta$-hs-oestrone-3-sulfate $(X)$. The final derivative was purified by silica gel column chromatography (silica gel 60, 230-400 mesh, Merck, Darmstadt; column bed volume $65 \mathrm{ml}$, flow rate $2 \mathrm{ml} \mathrm{min}^{-1}$, fraction size $5 \mathrm{ml}$ ) in ethyl acetate:methanol:ammonia (100:20:1 v/v). Fractions with $R_{F}$ values of 0.4 were pooled, evaporated and stored dry until further use. NMR in $\mathrm{CD}_{3} \mathrm{OD}$ gave $\delta$ p.p.m. $0.9\left(3 \mathrm{H}, \mathrm{S}, 18-\mathrm{CH}_{3}\right)$, $2.65\left(4 \mathrm{H}, \mathrm{S},-\mathrm{CO}-\left(\mathrm{CH}_{2}\right)_{2}-\mathrm{CO}\right), 6.0\left(1 \mathrm{H}\right.$, broad, $\left.6_{\beta}\right), 6.6-7.2$ (three aromatic protons $\mathrm{q}, \mathrm{d}, \mathrm{d} 2-1-4 \mathrm{H})$.

Stage (iv). The final process involved conjugation of the oestrone sulfate derivative to BSA (Sigma, St Louis, MO). This was achieved by activating the derivative using $N$-(3-dimethylaminopropyl)- $N^{\prime}$-ethylcarbodiimide and $p$-nitrophenol in dioxane at room temperature for $2.5 \mathrm{~h}$ (XI) (Nambara et al., 1980). The reaction mixture was developed by preparative TLC in chloroform:methanol (5:1) and the fractions with $R_{F}$ values of 0.4 were eluted and evaporated to dryness. Conjugation of the activated derivative with BSA was achieved by mixing the two in a mixture of pyridin:phosphate buffer $\left(0.1 \mathrm{~mol}^{-1}, \mathrm{pH} \mathrm{7.0)}\right.$ at 1:1 ratio, for $12-15 \mathrm{~h}$.

The hapten-BSA conjugate (XII) was dialysed extensively, freeze-dried and used for immunization.

\section{Antibodies}

Antiserum was raised in New Zealand rabbits $(2 \mathrm{~kg}$ body weight). The immunogen was dissolved in sterile phosphate- 
buffered saline $\left(0.5 \mathrm{moll}^{-1}, \mathrm{pH} 7.4\right)$ at a concentration of $1 \mathrm{mg} \mathrm{ml}^{-1}(0.5 \mathrm{ml})$ and emulsified with an equal volume of complete Freund's adjuvant. The emulsion was injected into the rabbits subcutaneously at multiple sites. The procedure was repeated a further three times at intervals of 3 weeks but with $0.1 \mathrm{mg}$ immunogen $\mathrm{ml}^{-1}$ in incomplete Freund's adjuvant. Blood samples were taken one week after the last booster injection. Boosting and blood sampling cycles were repeated at monthly intervals for approximately 12 months. The sera were separated by centrifugation at $3000 \mathrm{~g}$ for $5 \mathrm{~min}$, purified with caprylic acid (Steinbuch and Audran, 1969) and stored at $-20^{\circ} \mathrm{C}$ until use.

\section{Preparation of hapten-peroxidase conjugate}

Horseradish peroxidase was coupled to 3 -hemi-succinateoestrone by the standard mixed anhydride reaction (Munro and Stabenfeldt, 1984) to give a molar ratio of hormone:enzyme of 1:1 as determined according to Erlanger et al. (1957).

\section{Enzymeimmunoassay procedure}

Flat-bottomed microtitration plates (Maxisorb, Nunc, Kamstrup, Denmark) were coated with $100 \mu \mathrm{l}$ per well $\left(1 \mu \mathrm{g} \mathrm{ml}^{-1}\right)$ hyperimmune $\mathrm{IgG}$ in carbonate-bicarbonate buffer $\left(50 \mathrm{mmol}^{-1}\right.$; $\mathrm{pH}$ 9.6), overnight at $4{ }^{\circ} \mathrm{C}$ (Krambovitis et al., 1986). Excess antibody was washed off with distilled water containing $0.05 \%$ Tween 20 (Merck, Darmstadt) and the coated wells were blocked with $200 \mu \mathrm{l}$ per well of $1 \% \mathrm{w} / \mathrm{v}$ BSA in saline for $1 \mathrm{~h}$ at room temperature. Test milk samples, $50 \mu \mathrm{l}$, or corresponding volumes with standard concentrations of oestrone sulfate were added to wells in duplicate, $150 \mu \mathrm{l}$, respectively, of haptenperoxidase conjugate at working strength $(1 / 50000)$. The mixture was incubated at room temperature for $1 \mathrm{~h}$. After three washings with $0.05 \%$ Tween- 20 in distilled water, the antibody-antigen reaction was revealed by adding $100 \mu \mathrm{l}$ of substrate $\left(0.25 \mathrm{~mol} 3,3^{\prime}, 5,5^{\prime}\right.$ tetramethylbenzidine $1^{-1}, 0.03 \% \mathrm{v} / \mathrm{v}$ hydrogen peroxidase in $50 \mathrm{mmol}$ sodium acetate $\mathrm{I}^{-1}$ buffer $\mathrm{pH}$ 5.2) to each well. The reaction was stopped after $15 \mathrm{~min}$ by the addition of $50 \mu \mathrm{l}$ per well of $2 \mathrm{~mol}$ sulfuric acid $\mathrm{l}^{-1}$. The absorbance was measured at $450 \mathrm{~nm}$ (Multiskan, Flow, Finland).

\section{Results}

\section{Assay characteristics}

The assay we developed for measuring oestrone sulfate directly was based on the principle of direct competition of native hormone with the conjugate against the immobilized antibody. A key factor that influences the sensitivity of such an assay is the affinity of the antibody for the native hormone. Studies were made initially to identify antibodies with acceptable affinity by titration of immobilized rabbit anti $6 \beta$-hs-oestrone-3-sulfate (rabbit anti-oestrone sulfate antibodies), from different serum samples, against the conjugate alone (3-hs-oestrone-peroxidase, $2 \mathrm{mg} \mathrm{ml}^{-1}$, diluted 1:50 000) or in the presence of $5 \mathrm{ng}$ authentic oestrone sulfate $\mathrm{ml}^{-1}$ (Fig. 2). The results showed that antibodies

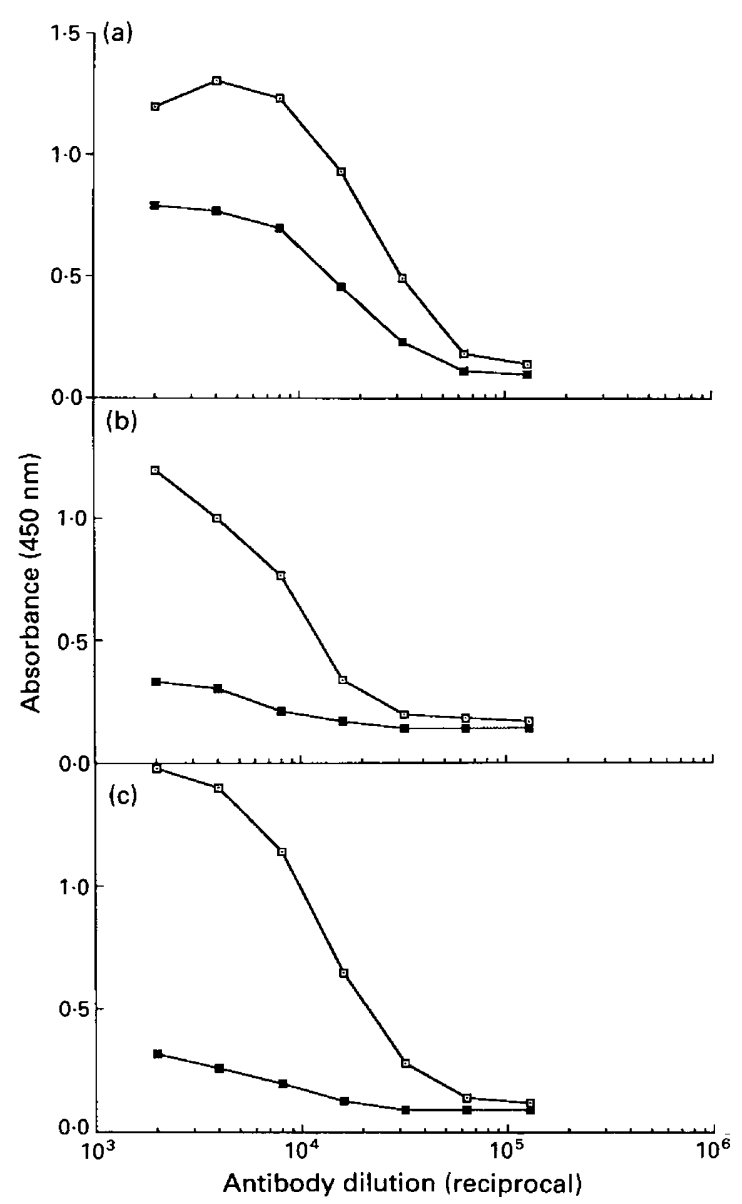

Fig. 2. Titration of hyperimmune rabbit anti-6 $\beta$-hemi-succinateoestrone sulfate against 3 -hemi-succinate-oestrone-peroxidase alone $(\square-\square)$ and with constant $5 \mathrm{ng}$ authentic oestrone sulfate $\mathrm{ml}^{-1}$ (ם- ) showing the differences in competitive inhibition of the first three serum samples taken during immunization; antiserum from the (a) first serum sample; (b) second sample, and (c) third sample.

from the first serum sample gave excellent reaction with the conjugate but poor inhibition ( $40 \%$ ) (Fig. 2a). A marked increase of the inhibitory effect of the antibodies was noted with the second sample (73\%) (Fig. 2b), which reached a maximum inhibition from the third sample (81\%) (Fig. 2c) onward. This effect was observed in the antibodies from all five animals immunized, although the maximum inhibition varied: two animals gave $81 \%$ inhibition with $5 \mathrm{ng}$ authentic hormone $\mathrm{ml}^{-1}$, one $65 \%$, one $53 \%$ and one $51 \%$.

Competitive inhibition studies were carried out to assess the degree of conjugate displacement in the assay. Titration of authentic oestrone sulfate in $10 \mathrm{mmol}$ potassium phosphate buffered saline $1^{-1} \mathrm{pH} 7.4$ containing $0.1 \% \mathrm{BSA}$ and in the presence of constant conjugate concentration (at working strength) against rabbit anti-oestrone sulfate antibodies from the third sample showed that 12.5 pg per well of authentic hormone was required to inhibit the reaction of the conjugate against the antibody by $50 \%$ (Fig. 3).

Oestrone sulfate standards in bovine milk were prepared for the calibration curve by adding appropriate amounts of hormone to milk taken 10 days after birth. Six standards were made 


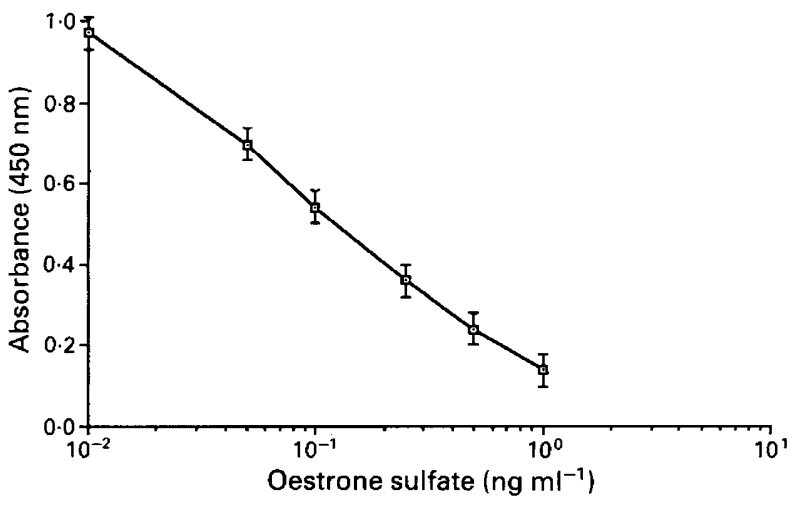

Fig. 3. Standard curve for oestrone sulfate in milk enzyme immunoassay from four different batches of standards (vertical bars represent $\mathrm{SD})$.

Table 1. Specificity of the antiserum with selected steroids

\begin{tabular}{lc}
\hline Steroid & \% Crossreactivity ${ }^{*}$ \\
\hline Oestrone sulfate & 100 \\
Oestrone & 11 \\
Oestradiol sulfate & 6.3 \\
Oestradiol & 0.3 \\
Oestradiol 3( $\beta$-D glucuronide) & 0.2 \\
Oestriol sulfate & 0.1 \\
Oestriol & $<0.1$ \\
Oestriol 3( $\beta$-D glucuronide) & $<0.1$ \\
Testosterone & $<0.1$ \\
Androstenedione & $<0.1$ \\
Dehydroepiandrosterone & $<0.1$ \\
Dehydroepiandrosterone sulfate & $<0.1$ \\
\end{tabular}

${ }^{*}$ Crossreactivity was defined as the amount of steroid, relative to oestrone sulfate, required to reduce conjugate binding by $50 \%$.

covering the intended range $\left(<0.01-1.0 \mathrm{ng} \mathrm{ml}^{-1}\right.$ oestrone sulfate) which were sufficient to discriminate between pregnant and nonpregnant animals (Fig. 3).

Sensitivity of the assay, calculated as the concentration of oestrone sulfate that could be detected three standard deviations above the value of the zero standard, was $0.03 \mathrm{ng} \mathrm{ml}^{-1}$ $(n=16)$.

Specificity experiments with twelve commercially available steroids (Steraloids, Wilton), indicated $11 \%$ crossreactivity with oestrone, $6.3 \%$ with oestradiol sulfate and less than $1 \%$ with all other steroids tested (Table 1 ).

Precision of the assay was assessed by replicate measurements of three unknown milk samples taken from pregnant cows at approximately 100 days of gestation. The intra-assay mean values obtained were $0.81 \mathrm{ng} \mathrm{ml}^{-1}(\mathrm{CV}=5.0 \%, n=16)$, $0.51 \mathrm{ng} \mathrm{ml}^{-1}(\mathrm{CV}=5.6 \%, n=16)$ and $0.138 \mathrm{ng} \mathrm{ml}^{-1}(\mathrm{CV}=$ $5.6 \%, n=16$ ). The corresponding interassay values using four different batches of reagents were $0.83 \mathrm{ng} \mathrm{ml}^{-1}(\mathrm{CV}=9.1 \%$,
Table 2. Recovery of authentic oestrone sulfate added to bovine milk

\begin{tabular}{lcccc}
\hline Basal & $\begin{array}{c}\text { Authentic } \\
\text { oestrone } \\
\text { sulfate } \\
\text { added } \\
\left(\mathrm{ng} \mathrm{m}^{-1}\right)\end{array}$ & $\begin{array}{c}\text { Expected } \\
\text { value } \\
\left(\mathrm{ng} \mathrm{m}^{-1}\right)\end{array}$ & $\begin{array}{c}\text { Observed } \\
\text { value }\end{array}$ & $\begin{array}{c}\text { Recovery } \\
\left(\% \mathrm{ng} \mathrm{m}^{-1}\right)\end{array}$ \\
\hline 0.02 & 0.2 & 0.22 & 0.25 & 113 \\
0.02 & 0.5 & 0.52 & 0.55 & 105 \\
0.07 & 0.2 & 0.27 & 0.29 & 107 \\
0.07 & 0.5 & 0.57 & 0.60 & 105 \\
0.5 & 0.2 & 0.7 & 0.7 & 100 \\
0.5 & 0.5 & 1.0 & 1.0 & 100 \\
\hline
\end{tabular}

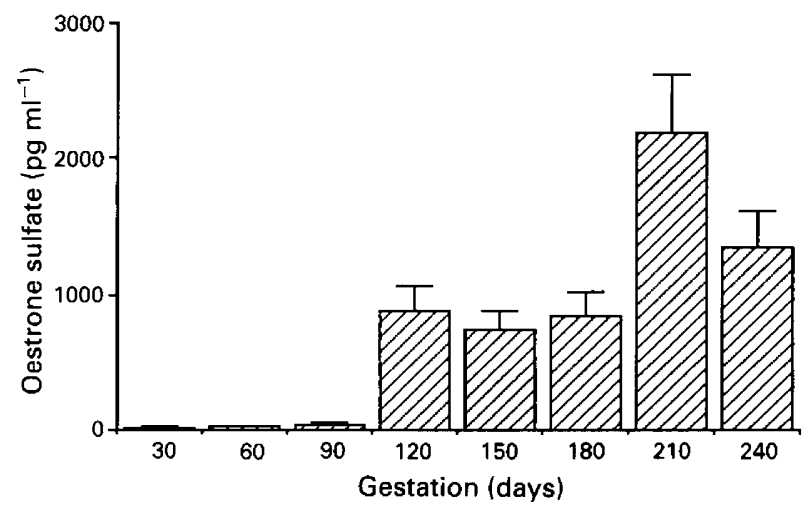

Fig. 4. Oestrone sulfate concentration in the milk of 20 cows during pregnancy as measured by enzymeimmunoassay (values are means $\pm \mathrm{SD})$.

$n=4), 0.50 \mathrm{ng} \mathrm{ml}^{-1}(\mathrm{CV}=8.8 \%, n=4)$ and $0.140 \mathrm{ng} \mathrm{ml}^{-1}$ $(\mathrm{CV}=8.5 \%, n=4)$.

Recovery of oestrone sulfate was investigated by adding authentic hormone to milk samples. The results (Table 2) indicated a recovery close to $100 \%$.

\section{Application of the assay in measuring oestrone sulfate during gestation}

The assay was used with milk samples taken from 20 pregnant cows at regular intervals throughout gestation. All the animals in the experiment subsequently calved normally. The results (summarized in Fig. 4) showed a low oestrone sulfate concentration in the first 90 days $\left(\leqslant 30 \mathrm{pg} \mathrm{m}^{-1}\right)$ followed by a sharp rise after day 100 . During months $4-6$ the average oestrone sulfate in the milk was $1 \mathrm{ng} \mathrm{ml}^{-1}$, followed by a rise to $2 \mathrm{ng} \mathrm{ml}^{-1}$ in month 7 and then a drop to $1.5 \mathrm{ng} \mathrm{ml}^{-1}$ in month 8 . The concentration of oestrone sulfate in 25 nonpregnant cows was $30 \mathrm{pg} \mathrm{ml}^{-1}(\mathrm{SD}=20)$. 


\section{Discussion}

In this study we have described a method for producing specific antibodies to oestrone sulfate as well as the development and evaluation of an immunoenzymatic method for measuring the hormone directly in bovine milk. Previous methods for measuring oestrone sulfate either required hydrolysis and extraction with organic solvents of the sample and estimation of free oestrone (Robertson et al., 1978), or estimated directly with anti-oestrone glucuronide antibodies (Wright et al., 1978) but with substantial crossreactions against related steroid hormones (Saba and Hattersley, 1981). A direct radioimmunoassay with specific antibodies was described later (Honjo et al., 1986) which was evaluated only with human samples.

The immunogen we prepared was designed to allow the specificity-determining sulfate group in the $\mathrm{C}-3$ position to be exposed for maximum immune response (Nambara et al., 1980). The final product was essentially the same as that reported previously (Nambara et al., 1980), although we described the complete sequence of 12 reaction steps starting from oestradiol. We preferred BSA as the protein carrier, despite our intention to use the antibodies with bovine samples, because of its high degree of purity which allowed us to control the coupling reaction more accurately. We avoided any potential interference in the bovine milk assays by including BSA in both the blocking and assay buffers. The assay we developed was based on the principle outlined below:

The conjugate consisted of oestrone with a hemi-succinate bridge in the C-3 position (for enzyme coupling) instead of the sulfate group. When a mixture of natural oestrone sulfate and conjugate was exposed to immobilized oestrone sulfate specific antibodies, there was a greater affinity for oestrone sulfate, thus enhancing the competitive inhibition of the conjugate (Hatzidakis et al., 1993) and increasing the sensitivity of the assay to a useful range. The observed sensitivity was $0.03 \mathrm{ng} \mathrm{ml}^{-1}$ in the milk. The assay was optimized to give the required discrimination necessary to study the concentrations of oestrone sulfate in the milk mainly during days $80-140$ of pregnancy. The quality of the antibodies played a crucial role in the effectiveness of the assay. Acceptable inhibition was obtained from the second hyperimmune serum sample onwards. The overall specificity of the antibodies was satisfactory, although crossreaction with oestrone $(11 \%)$ was higher than that reported by Nambara et al. (1980) (under 1.5\%). The crossreaction was attributed to the conjugate we elected to use to maximize sensitivity without affecting the specificity greatly. As free oestrone in body fluids is normally at very low concentrations, we did not experience any problems in specificity with test samples.

It is well established that detection of oestrone sulfate in animals is clearly associated with pregnancy. An immunoassay such as the one we have described could be used to provide strong evidence for the presence of a viable fetoplacental unit, thus giving the basis of a direct pregnancy test. Our assay was evaluated prospectively in a limitedscale field trial with milk from dairy cows. The results showed that the concentrations of oestrone sulfate in the milk of pregnant cows rose dramatically at approximately 100 days after insemination, remaining high throughout the remainder of the pregnancy, in agreement with a previous report (Holdsworth et al., 1982). As oestrone sulfate has been reported to be of diagnostic value in sows (Robertson et al., 1978; Wright et al., 1978; Saba and Hattersley, 1981), the assay has also been adapted to measure oestrone sulfate in the serum and urine of sows and is currently under evaluation.

The importance of oestrone sulfate concentrations in human body fluids and tissues as an indicator of normal and certain pathological conditions has been gaining momentum. This is supported by reports on the concentrations of oestrone sulfate during the menstrual cycle (Honjo et al., 1987), last trimester and delivery periods (Honjo et al., 1986), age-related conditions (Myking et al., 1980; Honjo et al., 1989) and oestrogen-dependent neoplasia (Naitoh et al., 1989). The simplicity, satisfactory sensitivity/specificity makes our assay a very useful tool with which to study and evaluate further the role and significance of oestrone sulfate in humans.

The authors would like to thank M. Papadopoulos of the University of Crete for his advice on the preparation of the immunogen.

\section{References}

Chaplin VM and Holdsworth RJ (1982) Oestrone sulphate in goat's milk Veterinary Record 111224

Dhindsa DS, Metcalfe J and Resko JA (1981) Oestrogen concentrations in systemic plasma of pregnant pygmy goats Journal of Reproduction and Fertility 62 99-103

Erlanger FB, Borek F, Beiser MS and Lieberman S (1957) Steroid protein conjugates. 1. Preparation and characterization of conjugates of bovine serum albumin with testosterone and with cortisone Journal of Biological Chemistry $228713-727$

Fletcher NA and Worsford AI (1988) A direct radioimmunoassay for oestrone sulphate in serum British Veterinary Journal 144 269-272

Hatzidakis G, Stefanakis A and Krambovitis E (1993) Comparison of different antibody-conjugate derivatives for the development of a sensitive and specific progesterone assay Joumal of Reproduction and Fertility 97 557-561

Heap RB and Hamon M (1979) Oestrone sulfate in milk as an indicator of a viable conceptus in cows British Veterinary Journal $135355-363$

Holdsworth RJ, Heap RB, Booth JM and Hamon M (1982) A rapid direct radioimmunoassay for the measurement of oestrone sulphate in the milk of dairy cows and its use in pregnancy diagnosis Joumal of Endocrinology 95 $7-12$

Honjo $\mathrm{H}$, Kitawaki J, Itoh M, Yasuda J, Yamamoto T, Okada H, Ohkubo T and Nambara T (1986) Serum and urinary oestrone sulfate in pregnancy and delivery measured by a direct radioimmunoassay Acta Endocrinologica 112 $423-430$

Honjo H, Kitawaki J, Itoh M, Yasuda J, Iwasaku K, Urabe M, Naitoh K, Yamamoto T, Okada H, Ohkubo T and Nambara T (1987) Serum and urinary estrone sulfate during the menstrual cycle, measured by a direct radioimmunoassay, and the fate of exogenously injected estrone sulfate Hormone Research $2761-68$

Honjo H, Ogino Y, Naitoh K, Urabe M, Kitawaki J, Yasuda J, Yamamoto T, Ishihara S, Okada H, Yonezawa T and Nambara T (1989) In vivo effects by estrone sulfate on the central nervous system - senile dementia (Alzheimer's type) Joumal of Steroid Biochemistry 34 511-515

Krambovitis E, Harris M and Hughes DTD (1986) Improved serodiagnosis of tuberculosis by a two-assay ELISA journal of Clinical Pathology 39 779-785

Longwell B and Wintersteiner $O$ (1940) Estrogens with oxygen in ring B. III. 6 keto a-estradiol Journal of Biological Chemistry 133 219-225

Loriaux DL, Ruder HL and Lipsett MB (1971) The measurement of oestrone sulfate in plasma Steroids 18 463-472

Munro C and Stabenfeldt G (1984) Development of a microtitre plate enzyme immunoassay for the determination of progesterone Joumal of Endocrinology 101 41-47

Myking O, Thorsen T and Stoa F (1980) Conjugated and unconjugated plasma oestrogens - oestrone, oestradiol and oestriol - in normal human males Journal of Steroid Biochemistry 13 1215-1220

Downloaded from Bioscientifica.com at 04/26/2023 01:29:58PM 
Naitoh K, Honjo H, Yamamoto T, Urabe M, Ogino Y, Yasumura T and Nambara T (1989) Estrone sulfate and sulfatase activity in human breast cancer and endometrial cancer Joumal of Steroid Biochemistry 33 1049-1054

Nambara T, Takahashi M and Numazawa M (1974) Syntheses of new haptens for radioimmunoassay of estradiol Chemical and Pharmaceutical Bulletin 22 1167-1173

Nambara T, Shimada K and Ohta H (1980) Preparation of specific antiserum to estrone sulfate Journal of Steroid Biochemistry 13 1075-1079

Power MJ, Cleere WF, Gosling JP, Fottrell PF, Langley OH and Sreenan JM (1985) A direct, high throughput, enzyme immunoassay for oestrone sulfate in the milk of cows Irish Veterinary Journal 39 18-24
Robertson HA, King GJ and Dyck GW (1978) The appearance of oestrone sulphate in the peripheral plasma of the pig in early pregnancy Journal of Reproduction and Fertility 52 337-338

Saba N and Hattersley JP (1981) Direct estimation of oestrone sulphate in sow serum for a rapid pregnancy diagnosis test journal of Reproduction and Fertility $6287-92$

Steinbuch $\mathbf{N}$ and Audran R (1969) The isolation of IgG from mammalian sera with the aid of caprylic acid Archives of Biochemistry and Biophysics 134 279-284

Wright K, Collins DC, Musey PI and Preedy JRK (1978) A specific radioimmunoassay for estrone sulfate in plasma and urine without hydrolysis Journal of Clinical Endocrinology and Metabolism 47 1092-1098 